\title{
Azithromycin-Induced Pill Esophagitis
}

\author{
Vincent Zimmer ${ }^{a, b}$ Kai Emrich ${ }^{c}$

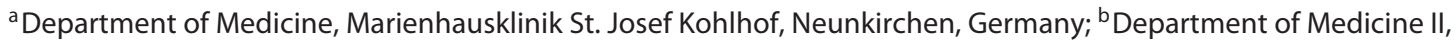 \\ Saarland University Medical Center, Saarland University, Homburg, Germany; ' Institute of Pathology \\ Saarbrücken-Rastpfuhl, Saarbrücken, Germany
}

Keywords

Dysphagia · Pill esophagitis · Esophageal ulcer · Chest pain

Esofagite induzida por comprimido de Azitromicina

\section{Palavras chave}

Disfagia · Esofagite por comprimidos - Úlcera esofágica · Dor torácica

A 21-year-old female presented for dysphagia and odynophagia with retrosternal localization for 4 days. Chest pain and/or accentuation during inspiration were not reported. Medical history included penicillin allergy and recent streptococcal pharyngitis as confirmed by microbial analysis of a throat swab diagnosed 12 days before. After prescription of cefuroxime for 5 days, antibiotic treatment was switched to a 5-day azithromycin regimen due to insufficient clinical response. Esophagogastroduodenoscopy (EGD) revealed three deep, well-demarcated esophageal ulcers estimated at $8 \mathrm{~mm}$ with slightly raised edges. Of note, in the absence of vesicles, all mucosal lesions were located at the same level at $27 \mathrm{~cm}$ from the in-

karger@karger.com www.karger.com/pjg

Karger:

BOPEN ACCESS
(C) 2020 Sociedade Portuguesa de Gastrenterologia Published by S. Karger AG, Basel

This article is licensed under the Creative Commons AttributionNonCommercial-NoDerivatives 4.0 International License (CC BY NC-ND) (http://www.karger.com/Services/OpenAccessLicense). Usage and distribution for commercial purposes as well as any distribution of modified material requires written permission. cisors on a background of an otherwise normal esophageal mucosa (Fig. 1a). Histopathology from the ulcer bed and rim indicated bland ulceration with a dense inflammatory infiltrate with edema of squamous cell epithelium without evidence for viral and/or fungal esophagitis (Fig. 1b, c: H\&E. $\times 5, \times 10$, respectively). Ancillary immunohistochemistry for herpes simplex virus type 1 and cytomegalovirus were unremarkable, respectively. Given a diagnosis of pill esophagitis for which there are no established and proven treatment options beyond stopping the offending substance, the patient was additionally treated with proton pump inhibitors and sucralfate suspension on an empirical basis. While dysphagia rapidly ceased, repeat EGD 14 days later revealed complete ulcer healing (Fig. 1d). Notwithstanding, the need for repeat endoscopy and its distinct timing may remain debatable.

As a newer-generation macrolide, azithromycin-related pill esophagitis presumably due to prolonged mucosal contact at physiological narrowings; e.g., as in this case the left main bronchus indentation, has only occasionally been reported in the literature, unlike for its acidic precursor substance doxycycline $[1,2]$. In our personal endoscopy experience, this unique report represents the first (and up to now only) clinical case of azithromycininduced pill esophagitis. Medication-induced esophageal 

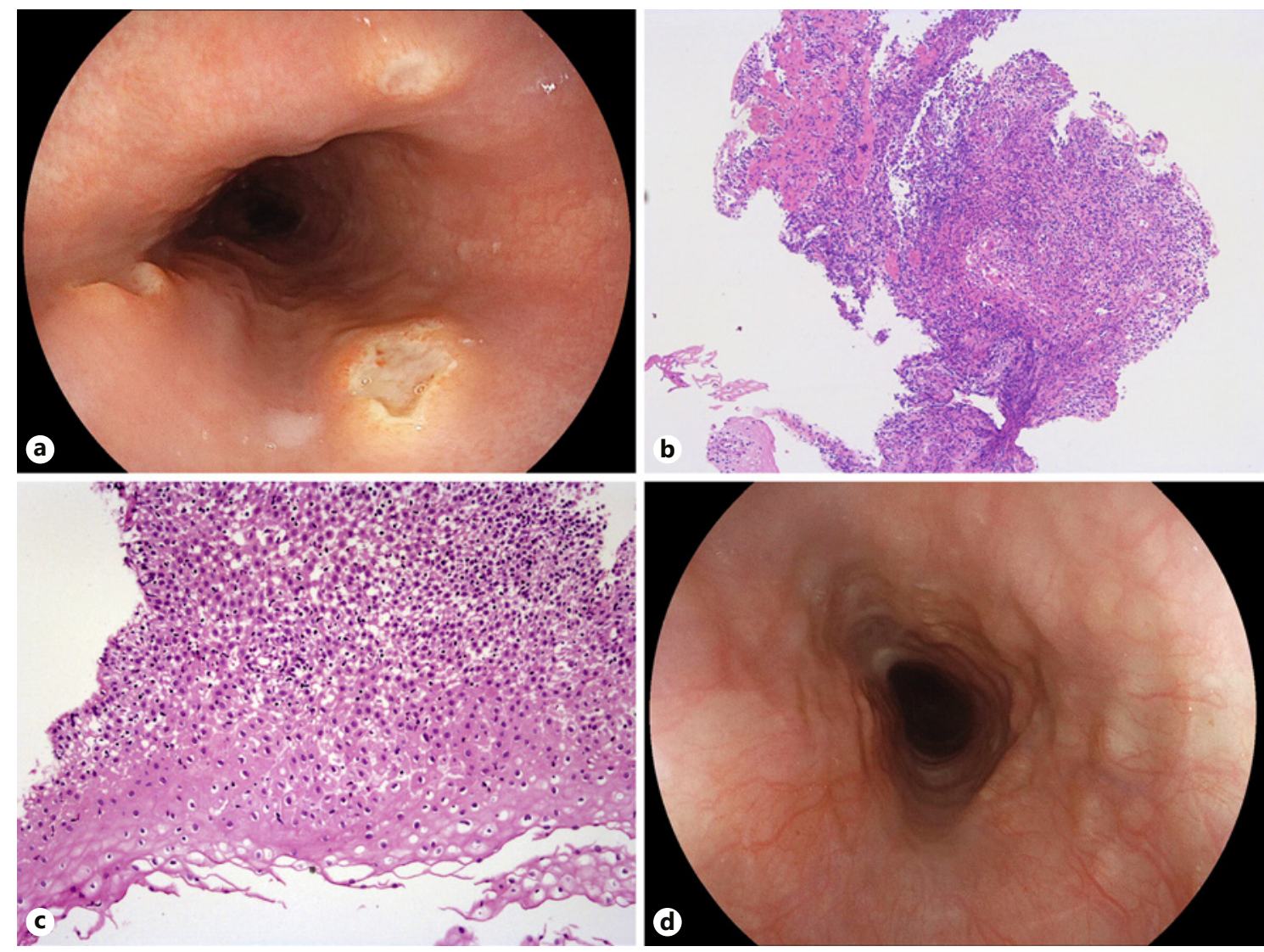

Fig. 1. a Esophagogastroduodenoscopy (EGD) demonstrating esophageal ulcers with an estimated maximum size of $8 \mathrm{~mm}$ and slightly raised borders. Note that all esophageal mucosal injury lesions are located at the same height within the esophagus at $27 \mathrm{~cm}$ from the incisors (most likely representing physiological narrowing due to the left main bronchus). b, $\mathbf{c}$ Biopsies from the ulcer bed and rim indicate bland ulceration with a dense inflammatory infiltrate and epithelial edema (H\&E. $\times 5, \times 10$, respectively). In addition, there is no evidence for viral esophagitis as substantiated by negative herpes simplex virus type 1 and cytomegalovirus immunohistochemistry (not shown). d Complete ulcer healing on repeat EGD 14 days later. injury may be prevented mainly by instructing patients to take oral medications with ample of water and avoiding immediate recumbency [3].

\section{Statement of Ethics}

The patient has given written informed consent for publication (including publication of images).

\section{Conflict of Interest Statement}

The authors have no conflicts of interest to declare.

\section{Funding Sources}

The authors did not receive any funding.

\section{Author Contributions}

V.Z.: clinical care, drafting, and finalization of the manuscript. K.E.: pathology, revision, and approval of the manuscript.

\section{References}

1 Gröchenig HP, Tilg H, Vogetseder W. Clinical challenges and images in GI. Pill esophagitis. Gastroenterology. 2006 Oct;131(4):996, 1365

2 Akyuz U, Erzin Y, Yalniz FF, Senkal IV, Ekici ID, Pata C. Severe odynophagia in a patient developing after azithromycin intake: a case report. Cases J. 2010 Feb;3(1):48.

3 Kikendall JW. Pill-induced esophagitis. Gastroenterol Hepatol (N Y). 2007 Apr;3(4):275-6. 